\title{
Some Thoughts on Tourism in Lao PDR: Communist Ideology and Touristic Reality
}

\author{
Robert M. Bichler
}

Shanghai International Studies University \& Unified Theory of Information Research Group, http://ww.uti.at/bichler, robert.bichler@uti.at

L ao People's Democratic Republic (Lao PDR) lies in the heart of continental SouthEast Asia and is one of the last remaining official communist states. The country was isolated from the outside world until the mid 1980s. In October 1989 Lao PDR was opened to international tourists and since then the Lao government has considered tourism as a crucial issue for development and therefore made more and more areas of the country accessible to foreign visitors (Yamauchi \& Lee, 1999, pp. 1-4). The importance of the tourism sector manifested in a total of 894806 tourists in the year 2004 . Thereby revenues of 118.9 million US\$ were generated, which makes tourism the top foreign revenue earner accounting for $7 \%$ of the Gross Domestic Product (Oula et al., 2006, p. 5). Besides cultural sights such as Luang Prabang, which is a World Heritage Site, the inherent natural beauty attracts an increasing number of tourists. Hiking in pristine rainforests, kayaking on numerous rivers or riding a bicycle through dozy villages are just a few activities favoured by the mainly below thirtyyears-old travellers. The tourist line-up is composed of Western and more and more Chinese group tours, which make a stopover in Luang Prabang on their sightseeing tour across South-East-Asia, before continuing for example to Siam Riep to visit Angkor. However, the majority of foreign visitors are socalled backpackers, for whom Lao PDR seems to be an ideal destination: a necessary daily budget ranging between 15 and 25 US\$, a tropical climate and the ubiquitous availability of drugs make Lao PDR a magical attraction for young backpackers. Since the country is landlocked, it seems that a beach, which is a standard that is often demanded by back- packers, is missing. The solution for this deficit can be found in the far south of the country, close to the boarder with Cambodia, where four thousand islands stretch over eighty kilometres along the Mekong river. The beaches on the three touristy developed islands Don Khong, Don Det and Don Khon cannot keep up with the ones that can be found for example in Thailand, but for quite a few travellers the restaurants' menus, on which 'funny' or 'happy' dishes can be found, compensate for this. Serving meals 'funny' or 'happy' in tourist areas, i.e. seasoning dishes with marihuana or hallucinogenic mushrooms, is also common in Cambodia and Thailand. In the later case, due to the execution of stricter laws, this practice is more and more vanishing.

In a country where, based on a sole regnant political ideology, Western consumerism is considered to be evil, a parallel society exclusively made up by and for Western travellers, totally apart of the Lebenswelt (life world) of Lao citizens, has been established. Vang Vieng, the Lao counterpart of Thailand's Krabi and China's Yangshuo, is probably the most prominent enclave of this sort. The idyllically situated village is only $156 \mathrm{~km}$ from the capital Vientiane. About fifteen years ago Vang Vieng, surrounded by limestone hills and numerous caves and caverns, was an inconsiderable farming village that functioned as a rest stop on the north-south route. This changed dramatically when the country was opened up for foreign visitors. Although Vang Vieng has no manufacturing industry, it might be called a special economic area, in which deregulated tourism is practised, characterised by an omnipresent full moon party ambi- 
ence. Nam Xong River, which bypasses the village, is the partying epicentre for Western tourists. The small Nam Xong Island, just in front of Vang Vieng, consists of about six bars, where all sorts of strong alcoholic drinks are served in buckets, accompanied by loud techno music. The island is a very popular stop for backpackers after a long day tubing down the river. Tubing is perhaps the most peculiar phenomenon in Vang Vieng; for about four kilometres one floats down the river in an enormous tractor tube passing by more than twenty makeshift bars. The three hours plus, depending on the number of stops and resulting drinks, intoxicated ride ends right at the bank of Nam Xong Island, where the party continues far into the night. This is even more remarkable, given that the regime constricts civil rights and keeps an eye on almost all areas of the citizens' lives, including the monitoring of the media and the Internet, and the denial of the freedom of assembly and of free elections.

Tourism in Lao PDR can be considered as a (neo-) liberal niche, where everything seems to be permitted for Western tourists in search of distraction and great experience. Tourism, in this context, has been legitimized by ahistoric arguments, such as the invocation of exploration and curiosity as eternal characteristics of the conditio humana and, more recently, by claims to guarantee the economical sustainability of tourist destinations, in order to provide capitalism, or in the case of Lao PDR, the Chinese model of capitalism, with the possibilities to exploit the enormous profits promised by the tourist gaze.

\section{References}

Oula, Th., Sundara, K., Soulideth, Ch., Somsouk, S., Sisava, B. \& Vongphachamh, S. (2006). International Tourism: SocioEconomic Impacts in the Lao PDR. Technical Background Paper for the third National Human Development Report Lao PDR 2006. Vientiane: Lao National Tourism Administration (LNTA).

Yamauchi, S. \& Lee, D. (1999). Tourism Development in the Lao People's Democratic Republic. Discussion Paper No. 9 of the United Nations Department of Economic and Social Affairs. United Nations. Retrieved March 2008 from: http://www.un.org/esa/desa/papers/1999/esa99dp9.pdf

\section{About the Author}

Robert M. Bichler

Robert M. Bichler is lecturer at the Shanghai International Studies University (SISU) and member of the Unified Theory of Information (UTI) Research Group - Association for the Advancement of Information Sciences. Prior he was a research fellow and lecturer at the ICT\&S Center, University of Salzburg. Address: Shanghai International Studies University, German Department, 550 Da Lian Road (W), Shanghai 200083, P.R. China. [email: robert.bichler@uti.at] 